Michał Kurzej

https://orcid.org/0000-0003-1786-8650

Instytut Historii Sztuki

Uniwersytet Jagielloński

https://doi.org/10.18778/2084-851X.09.06

\title{
Kaplice kolegiaty św. Anny $w$ Krakowie - indywidualne fundacje pod zbiorczym nadzorem
}

Streszczenie. Krakowska kolegiata św. Anny jest przykładem rzadkiej sytuacji, w której odrębne finansowanie poszczególnych kaplic udało się pogodzić ze ścisłym zintegrowaniem ich wystroju z całością wnętrza, ale też bardzo specyficznej komemoracji ich dobrodziejów. Upamiętniono ich w książce wydanej z okazji konsekracji, co stanowiło specyficzny wyraz kultury akademickiej, skoncentrowanej na słowie pisanym, a także odwołującej się często do księgi jako uniwersalnego symbolu mądrości. W kościele św. Anny jest to główny motyw wnętrza, powtarzający się jako atrybut patronki, spis ziemskich przodków jej wnuka, dowód świętości Jana Kantego, znak wiedzy antycznych prorokiń oraz godności Baranka Apokaliptycznego jako Najwyższej Mądrości Bożej.

Słowa kluczowe: sztuka nowożytna, kościół, kaplice, Sebastian Piskorski, Uniwersytet Jagielloński

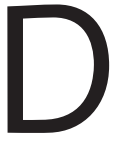

zieje artystyczne krakowskiej kolegiaty uniwersyteckiej były już przedmiotem licznych opracowań ${ }^{1}$. Postawienie w centrum zainteresowania jej kaplic narzuca jednak nieco odmienną perspektywę, związaną z kwestią patronatu nad poszczególnymi oratoriami i sposobem, w jaki ich dekoracja została włączona w ideowy i artystyczny program całego kościoła. Po jej przyjęciu kościół św. Anny jawi się jako ciekawy przyczynek do refleksji nad zjawiskiem mecenatu zbiorowego, doskonale potwierdzający pogląd Petera Hirschfelda i Michaela Baxandalla, według których termin ten odnosi się w zasadzie do działalności jednostki ukrytej za kolektywem ${ }^{2}$.

1 Bukowski 1900; Pagaczewski 1909; Mossakowski 1965; MaślińsKa-Nowakowa 1969; MaŚlińsKa-NowaKowa 1971; Karpowicz 1990; Kracik 2003; KurZej 2008; Kurzej 2018a.

2 Hirschfeld 1968, s. 10; BAXNADAll 1974, s. 5. Na stanowisko obu badaczy zwróciła uwagę Ewa Śnieżyńska-Stolot w tekście stanowiącym podstawowy przegląd poglądów na zagadnienie mecenatu, zob. ŚNIEŻYŃSKA-STOLOT 1981, s. 6. 
Jednym z celów, jakie stawiali sobie twórcy okazałego nowożytnego kościoła o bogatym programie liturgicznym i architektonicznym, było osiągnięcie możliwie jak największej spójności wystroju - zarówno pod względem ideowym, jak artystycznym. Podstawową przeszkodą w jego osiągnięciu był długi czas budowy, który często rozciągał się jeszcze ze względu na skomplikowane stosunki własnościowe, wynikające ze zróżnicowanego patronatu nad poszczególnymi ołtarzami. Jego przyczyną był zwyczaj przekazywania ich w opiekę bractwom, organizacjom lub rodzinom w zamian za współfinansowanie prac budowlanych i dekoratorskich. Ponieważ takie ołtarze planowano przede wszystkim w wyodrębnionych architektonicznie kaplicach bocznych, pozostawienie urządzenia takich wnętrz w gestii ich patronów stało się szybko powszechną praktyką, która poważnie utrudniała kontrolę nad ich programem i wystrojem ze strony właścicieli całego kościoła. Problem ten ujawnił się wyraźnie w przypadku wielkich „fabryk” kościelnych szesnastowiecznego Rzymu. Pierwsza z nich - kościół Imienia Jezus (Il Gesu) - napotkała poważne trudności po śmierci głównego fundatora, kardynała Alessandra Farnesego, w roku 1598. O ile sam Farnese, traktując budowlę jak swoją prywatną własność, osobiście podejmował większość decyzji i czuwał na ich wykonaniem, to jego spadkobiercy nie tylko wstrzymali finansowanie prac, ale też uchylali się od podjęcia kluczowych decyzji w sprawie dekoracji apsydy i ołtarza głównego, które Alessandro zagwarantował w testamencie swoim sukcesorom. Dalsze prace mogły więc postępować tylko w kaplicach bocznych, których patroni częściowo przejęli inicjatywę, urządzając wnętrza według własnej koncepcji i samodzielnie zatrudniając artystów. Tak powstały m.in. wybitne freski Federica Zuccariego w kaplicy Aniołów, zaś w pozostałych wnętrzach, ze względu na problemy finansowe, jezuici najchętniej zatrudniali słabszych artystów zakonnych. Całościowy efekt był więc bardzo daleki od jednorodności artystycznej i programowej. Analogiczne problemy wystąpiły też przy budowie jezuickiego kościoła św. Ignacego i teatyńskiego św. Andrzeja „della Valle”.

Na tym tle wyjątkiem okazał się natomiast nowy kościół Oratorianów „w Valicelli”, budowany pod kierunkiem samego Filipa Neriego, a potem uzupełniany według jego koncepcji. Założyciel zgromadzenia nie tylko nadzorował prace, decydując m.in. o znacznym powiększeniu budowli w stosunku do pierwotnego projektu, ale też ułożył program ikonograficzny o treściach mariologicznych. Był on konsekwentnie realizowany także po śmierci świętego i obejmował również kaplice boczne, które powierzano prywatnym patronom pod wyraźnym warunkiem dostosowania się do całościowej koncepcji wnętrza .

\footnotetext{
HASKell 1963, s. 66, 83; LeVy 1999-2000.

4 DANieli 2009, s. 81-122.
} 
Taka sytuacja przez cały wiek XVII należała jednak do wyjątków, podczas gdy problemy napotkane przez jezuitów w Rzymie powtarzały się bardzo często też w innych miastach Europy, oczywiście nie tylko w budowlach tego zakonu. Charakterystycznym przykładem jest krakowski kościół św. św. Piotra i Pawła, będący dla świątyni akademickiej istotnym pierwowzorem architektonicznym, a także najistotniejszym punktem odniesienia ze względu na ostrą rywalizację obu organizacji ${ }^{5}$. Przed konsekracją w roku 1619 udało się tam ozdobić tylko apsydę i (przynajmniej częściowo) kopułę, natomiast prace w kaplicach podejmowano dopiero po pozyskaniu dla nich odrębnych fundatorów. Część z nich udało się przeprowadzić w latach 30 i 40. wieku XVII, a ostatnie przypadły dopiero na lata 70. i $90 .^{6}$ Proces urządzania kościoła jezuickiego był więc tak rozciągnięty w czasie, że nałożył się na okres powstawania kolegiaty akademickiej.

Kamień węgielny kościoła św. Anny położono w roku 1689, ale prace ruszyły na dobre dopiero od roku 1693, po tym, jak nadzór nad nimi objął prof. Sebastian Piskorski, który prowadził je do konsekracji w roku 1703. On też odpowiadał za obsługę księgową przedsięwzięcia, które dzięki stabilnemu finansowaniu udało się zakończyć w zaledwie 10 lat, pomimo dramatycznych wydarzeń wojny północnej, a w szczególności okupacji szwedzkiej i związanej z nią kontrybucji. Nie zdołał on jedynie ukończyć ambony, stalli i organów, a elementy te wykonano długo po jego śmierci. Żaden z nich nie zakłócił jednak harmonii wnętrza, a przynajmniej ten ostatni zrealizowano według jego wskazówek

Dla osiągnięcia tej harmonii włączenie kaplic do programu treściowego wnętrza miało pierwszorzędne znaczenie, szczególnie ze względu na kaplice transeptowe. To w jednej z nich musiał się bowiem znaleźć szczególnie ważny element wnętrza, jakim jest ołtarz grobu św. Jana Kantego (il. 1), a takie usytuowanie pozwalało skierować na niego bezpośrednie światło w rocznicę urodzin patrona uniwersytetu. Odpowiednią oprawę musiała więc uzyskać przeciwległa kaplica św. Krzyża (il. 2), przypominająca o jego pobożności pasyjnej i prezentująca Krzyż jako źródło mądrości

Dużą wagę przykładano też do mniejszych oratoriów przynawowych. Są ich trzy pary, spośród których środkowa została wyróżniona wyższą kopułą z latarnią. Już sam dobór patronów kaplic przynawowych ma charakter alegoryczny - środkową kaplicę po stronie Epistoły dedykowano Marii Pannie (il. 3), a sąsiednie - Jej oblubieńcowi, św. Józefowi (il. 4), i krewnemu, św. Janowi Chrzcicielowi (il. 5). Przypomniano tam więc najważniejsze postaci rodziny Marii. Oratorium Chrzciciela

\footnotetext{
Na temat konfliktu uniwersytetu z jezuitami zob. URBAN 1964; NATOŃSKI 2002.

KurZej 2012, s. 337-341.

KurZej 2018a, s. 44-66.

$8 \quad$ Ibidem, s. 136.
} 
TECHNE

\begin{tabular}{l|l} 
T E X N H & 120
\end{tabular}

SERIA NOWA

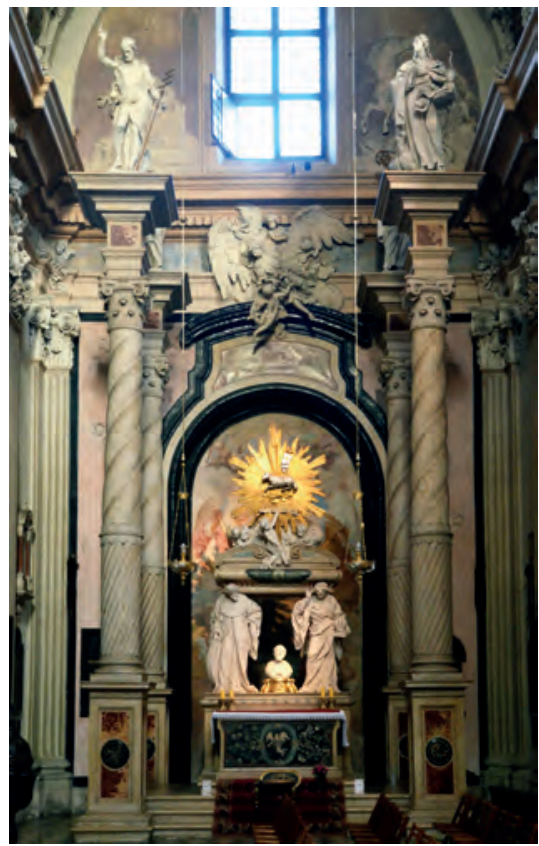

1. Kraków, kościół św. Anny, ołtarz św. Jana Kantego, fot. autor, 2017

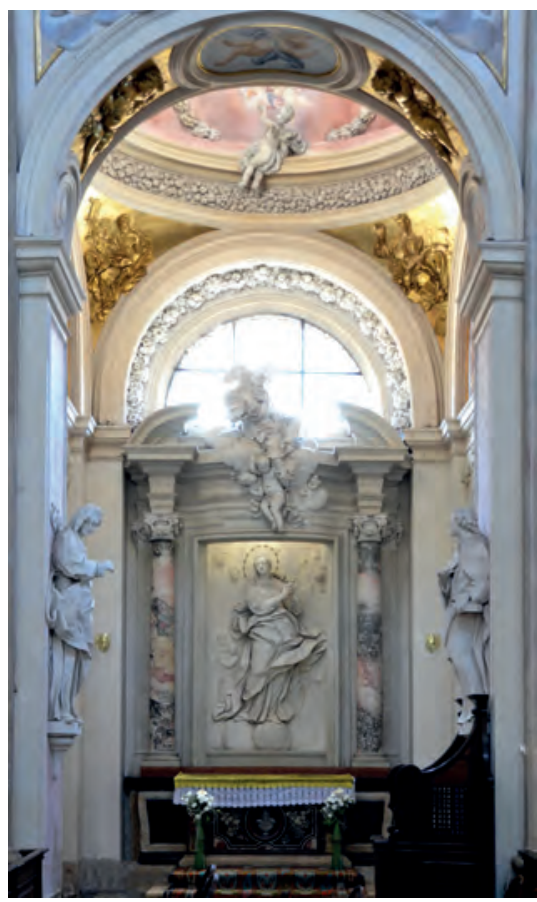

3. Kraków, kościół św. Anny, wnętrze kaplicy Matki Boskiej, fot. autor, 2017



2. Kraków, kościół św. Anny, ołtarz św. Krzyża, fot. autor, 2017

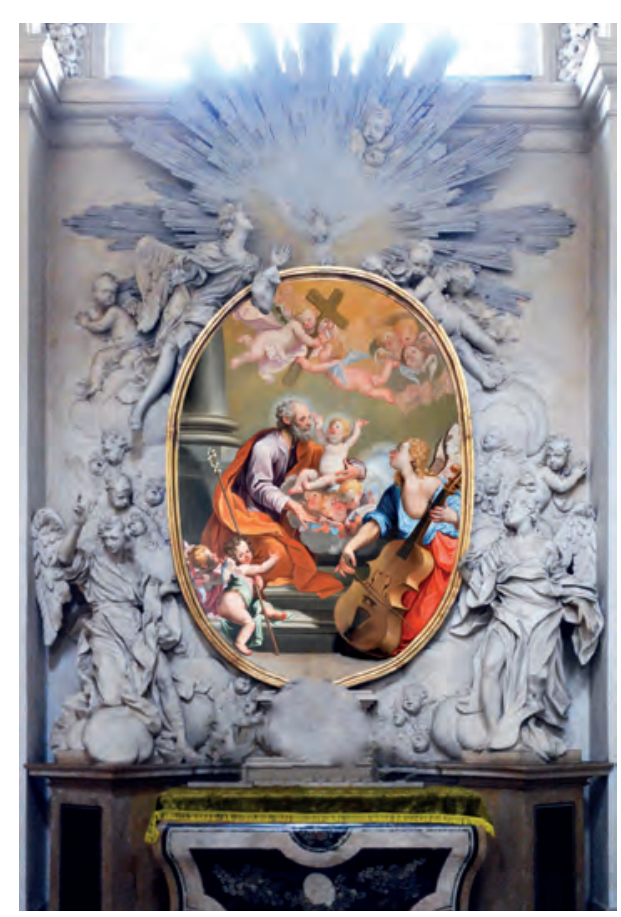

4. Kraków, kościół św. Anny, ołtarz św. Józefa, fot. autor, 2017 
sąsiaduje ponadto z mauzoleum Kantego, który przyszedł na świat w dzień przesilenia letniego, dziedzicząc jego imię. Natomiast kaplice strony Ewangelii dedykowano postaciom reprezentującym Kościół czasów Nowego Przymierza. Jego pierwszy zwierzchnik - św. Piotr - naśladujący Chrystusa w męczeństwie, został upamiętniony w sąsiedztwie kaplicy św. Krzyża. Środkowe oratorium, naprzeciw kaplicy Mariackiej, dedykowano św. Katarzynie dziewicy (il. 6), a ostatnie - św. Sebastianowi (il. 7), patronowi Piskorskiego, ale też popularnemu orędownikowi chorych zakaźnie, podobnie jak przedstawieni na ścianach bocznych Roch i Aleksy.

Wezwania kaplic są też powiązane z ikonografią sklepienia nawy, na którym w głównych polach zilustrowano opisaną w piątym rozdziale Apokalipsy chwałę Baranka otwierającego księgę, w lunetach zaś ukazano personifikacje ośmiu ewangelicznych błogosławieństw oraz odnoszących się do nich cnót. Jak zauważyła Zofia Maślińska-Nowakowa, ich układ został skorelowany z wezwaniami kaplic w taki sposób, by te uosobienia bądź ich atrybuty stanowiły aluzje do poszczególnych świętych. Do wezwań kaplic odnoszą się też niektóre proroctwa sybilli namalowanych nad ich arkadami ${ }^{9}$.

Jednorodność kaplic przynawowych i głównej przestrzeni kościoła widoczna jest również pod względem formalnym. Przesądza o tym jednak przede wszystkim wystrój sztukatorski autorstwa Baltazara Fontany, gdyż w partiach malarskich widać istotne różnice. Głównym autorem fresków w kaplicach był bowiem Innocenty Monti, który poza nimi pracował tylko przy ścianach mauzoleum Kantego. Mniejszy wkład w dekorację kaplic miał Karol Monti - autor przedstawień sybilli w nawie - który pomalował pendentywy oratorium św. Piotra, podczas gdy Karol Dankwart - autor głównych fresków sklepiennych kościoła - namalował tam tylko niewielkie medaliony w arkadach kaplicy św. Sebastiana. Tę drobną pracę powierzono mu zresztą w czasie, gdy Montich prawdopodobnie nie było jeszcze w Krakowie ${ }^{10}$.

Ta artystyczna spójność nie obejmuje jednak samych ołtarzy, których struktury odpowiadają sobie w poszczególnych parach, a różnią się od sąsiednich potraktowaniem elementów architektonicznych. W pierwszej parze od strony ołtarza głównego ograniczono je do obramień i podwieszonych wsporników, w ostatniej natomiast zupełnie $\mathrm{z}$ nich zrezygnowano na rzecz swobodnych kompozycji plastycznych z trzymającymi płótna figurami aniołów. Tradycyjna struktura edikulowa została zachowana tylko w kaplicy Mariackiej (il. 3), gdzie pole ołtarzowe oświetlono przez otwór ukryty za gzymsem. W przeciwległym ołtarzu św. Katarzyny na zbliżonym rzucie ustawiono urwane kolumny nawiązujące do biblijnej symboliki słupa obłoku ${ }^{11}$ (il. 6). Zróżnicowane są też obrazy ołtarzowe, z których tylko dwa

9 MAŚlińSKA-NOWAKOWA 1971, s. 44-46.

10 AUJ, 318, s. 203, 248-253, 256-259, 263; KURZEJ 2018a, s. 279-281.

11 KurZej 2018b, s. 234. 
mają wspólnego autora - nie jest on jednak tożsamy z twórcą płótna w polu głównej nastawy kościoła. Innocenty Monti namalował św. św. Piotra (il. 9) i Józefa (il. 4), Karol Dankwart ukazał scenę chrztu Chrystusa (il. 5), a obraz swojego patrona Piskorski zamówił u samego Paola Paganiego (il. 8). Można jednak przypuszczać, że taka malarska różnorodność była efektem zamierzonym, mającym na celu stworzenie jakiejś namiastki galerii dzieł wybitnych twórców tamtego czasu ${ }^{12}$. Najprawdopodobniej Piskorski dostrzegał różnice artystyczne pomiędzy poszczególnymi obrazami, a niewątpliwie widział różnice $\mathrm{w}$ ich wartości. Świadczy o tym fakt, że utajniając wydatki na urządzenie fundowanej przez siebie kaplicy własnego patrona zdecydował się jednak wspomnieć, że jej obraz wyceniano na 100 talarów. Dzięki temu można zauważyć znaczącą różnicę w stosunku do honorariów innych malarzy, gdyż Monti otrzymał jedyne 60 talarów za obraz ukazujący św. Piotra i 50 za przedstawienie św. Józefa, a Dankwart - zaledwie 40 za Chrzest Chrystusa ${ }^{13}$. Droższy był tylko znacznie większy obraz Siemiginowskiego do ołtarza głównego, za który zapłacono 1000 tynfów, czyli ok. 150 talarów ${ }^{14}$.

Kościół św. Anny jest niezwykły przede wszystkim ze względu na tempo robót murarskich i następujących bezpośrednio po nich prac dekoratorskich. Ich szybkie ukończenie było zaś możliwe dzięki stabilnemu finansowaniu, pochodzącemu głównie ze środków uniwersytetu, ale wspomaganemu przez szeroką kwestę, w której udział wzięły najznaczniejsze osoby w państwie. Najhojniejszy był biskup krakowski Jan Małachowski, który zapisał na ten cel 16000 złotych polskich, znaczący wkład (2000-4000 złotych) wnieśli też sufragan krakowski Stanisław Szembek oraz podczaszy warszawski Jan Wawrzyniec Wodzicki i marszałek nadworny koronny Hieronim Augustyn Lubomirski (dwaj ostatni wspólnie z małżonkami). W sumie największe były jednak ofiary prywatne profesorów uniwersytetu na czele z samym Piskorskim, którego wkład można szacować na ok. 3000 złotych polskich ${ }^{15}$. Na taką kwotę wskazuje porównanie do kosztów urządzenia przeciwległej kaplicy św. Józefa, rzeczywisty koszt mógł być jednak znacznie niższy, gdyż można przypuszczać, że profesor skłonił zatrudnionych artystów do znacznych zniżek. Urządzenie kaplicy św. Sebastiana miało duże znaczenie dla powodzenia całego przedsięwzięcia. Prace przy niej prowadzono bowiem równolegle $\mathrm{z}$ tymi w prezbiterium, a kaplica była pierwszą częścią ukończonego kościoła, którą udostępniono publicznie, prawdopodobnie już w roku $1696^{16}$. Przełomowe znaczenie tego wydarzenia dla sztuki

\footnotetext{
12 Podobna sytuacja miała również miejsce w rzymskim kościele Oratorianów, gdzie w ciągu 15 lat umieszczono m.in. dzieła Baroccia, Carravaggia i Rubensa, zob. Haskell 1963, s. 71.

13 AUJ, 318, s. 249, 256, 259.

14 Ibidem, s. 12.

15 Ibidem, s. 1-45.

16 Kurzej 2018a, s. 59.
} 
$123 \mid \begin{gathered}\text { TECHNE } \\ \text { TEX N H } \\ \text { sERIA NOWA }\end{gathered}$

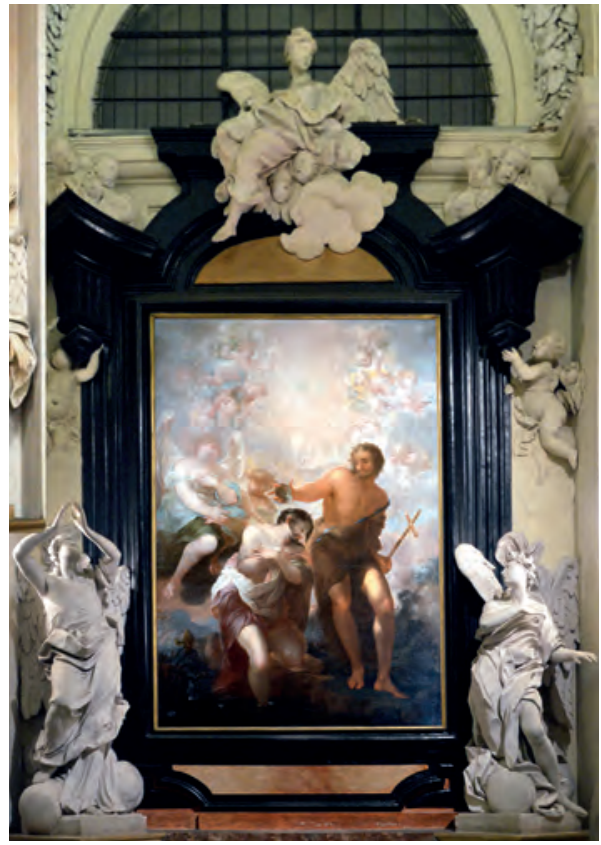

5. Kraków, kościół św. Anny, ołtarz św. Jana Chrzciciela, fot. autor, 2017

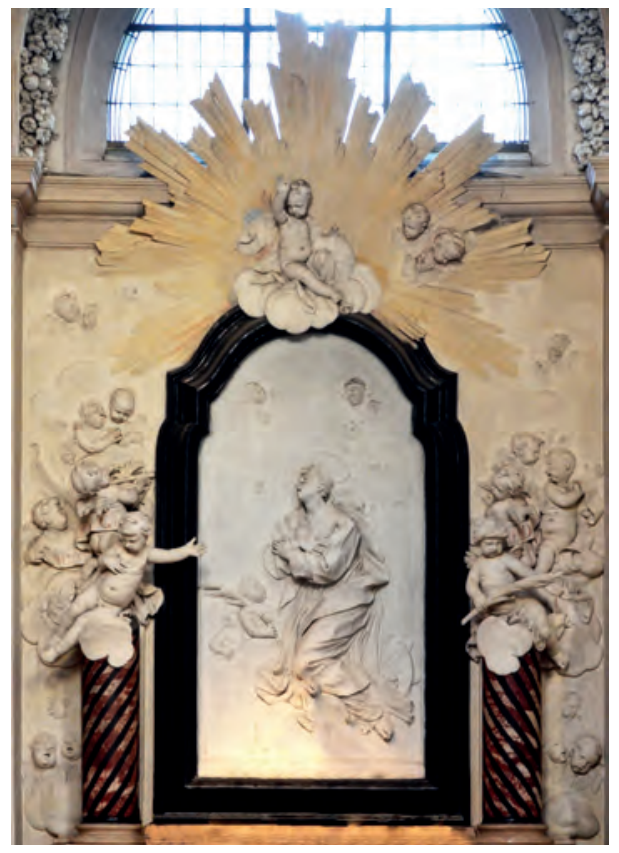

6. Kraków, kościół św. Anny, ołtarz św. Katarzyny, fot. autor, 2017

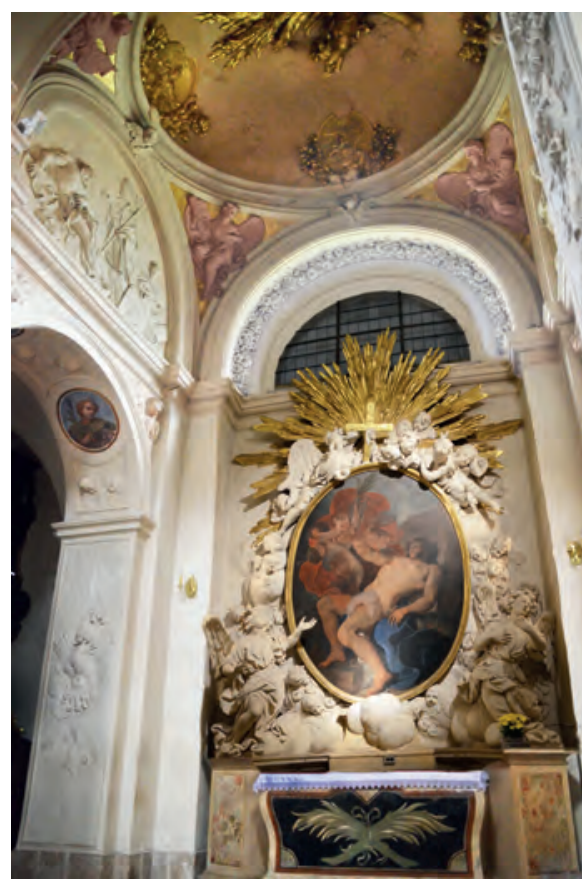

7. Kraków, kościół św. Anny, wnętrze kaplicy św. Sebastiana, fot. autor, 2017

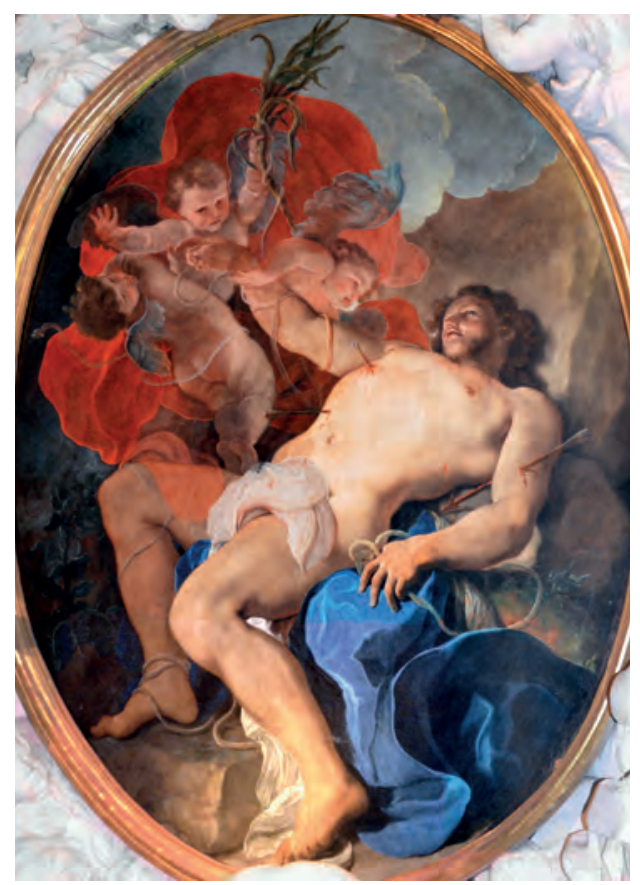

8. Kraków, kościół św. Anny, Paolo Pagani, Święty Sebastian, fot. autor, 2017 
Krakowa zostało dostrzeżone przez współczesnych i odnotowane w książce wydanej przez Andrzeja Buchowskiego z okazji konsekracji kościoła:

\begin{abstract}
Adeoque primum a foribus sacellum ipsemet D. Director Fabricae honori S. Sebastiani patroni sui extruxit, fornicem circularem, adinstar sacellorum Paduane S. Iustinae applicando. In eo sacello, excellens stucator Fontana altare per modum serti nubiferi cherubinis adornati et ad fenestram gloria caelatoria evecti, mirificum extruxit. Ad utrumque serti latus, cherubinum admirantem, dolentemque super passione D. Martyris, manu tenentem elegantem tabulam S. Sebastiani, opera M. Pauli Pagari [sic] Mediolanen[si] picta, et supra tabulam genios coelestes palmaria martyris signa portantes ad gloriam applicavit. [...] Hoc sacellum motivum dedit praesenti, nec hactenus viso, futurae ecclesiae ornatui ${ }^{17}$.
\end{abstract}

Można przypuszczać, że Piskorski, występując w tym przypadku nie tylko jako konceptor i prowizor, ale też jako prywatny fundator, starał się swoim przykładem zachęcić innych dobrodziejów do wsparcia dalszych prac dekoratorskich. Wydaje się, że był to zabieg skuteczny, gdyż w następnych latach udało się znaleźć fundatorów pozostałych kaplic bocznych. Duże znaczenie miał też przykład biskupa Jana Małachowskiego, który 22 maja 1695 roku publicznie obiecał wesprzeć prace wspomnianą sumą. Znaczącym dobrodziejem był też późniejszy ordynariusz, Kazimierz Łubieński, który od początku roku 1695 wspierał urządzanie mauzoleum św. Jana Kantego, przekazując łącznie kwotę 6887 złotych polskich ${ }^{18}$. Obaj hierarchowie brali udział $\mathrm{w}$ innych znaczących przedsięwzięciach artystycznych. Małachowski ufundował krakowski kościół Wizytek, zbudowany w latach 1692-1695, a więc współcześnie z kolegiatą, niestety przy udziale lokalnych artystów o nieporównywalnie mniejszych możliwościach ${ }^{19}$. Łubieński był zaś najprawdopodobniej inicjatorem budowy hełmu katedralnej wieży zegarowej, którą przeprowadzono w latach 1715-1716 według anonimowego, choć niewątpliwie wybitnego projektu, tworząc jedno z najambitniejszych dzieł tego typu ${ }^{20}$.

\footnotetext{
17 Buchowski 1703, k. F4v, Gr. W tłum.: Pierwszą kaplice przy wejściu do kościoła sam Pan Dyrektor Fabryki urządził na chwałe swojego patrona św. Sebastiana, nakrywając ją kolistym sklepieniem, na wzór kaplic kościoła św. Justyny w Padwie. W tej kaplicy znakomity sztukator Baltazar Fontana wykonat godny podziwu ołtarz w kształcie wieńca $z$ obłoków, ozdobionego cherubinami $i$ niebiańska gloria wyciagniętą $w$ strone okna. Po obu stronach tego wieńca [sztukator] ustawit figury aniołów podziwiających i opłakujących mękę św. męczennika, które trzymają wytworny obraz św. Sebastiana, namalowany przez Mediolańczyka Paola Paganiego, a nad obrazem umieścit niebiańskich geniuszy, wynoszących do chwały palmy, będące znakiem męczeństwa. [...] Kaplica ta zapoczątkowała ozdabianie nowego kościoła w formach, jakich dotychczas nie widziano.

18 AUJ, 318, s. 7, 37, 38.

19 IgNASZEWSKa 1976; KurZej 2012, s. 159, 160, 385, 390.

20 LePiarCZyK/PrZybysZeWski 1991, s. 22.
} 
Koszt urządzenia każdej z kaplic przynawowych wahał się od ok. 2600 złotych polskich w przypadku oratoriów św. św. Jana Chrzciciela i Józefa, do prawie 3900 złotych w kaplicy św. Piotra. Każda z nich miała głównego darczyńcę, który pokrył większość lub całość kosztów. Jedynym świeckim w tym gronie był wojski sądecki Aleksander Myszkowski, który ofiarował 3100 złotych polskich na kaplicę św. Józefa. Koszt urządzenia kaplicy św. Katarzyny pokrył archidiakon krakowski Remigiusz Suszycki. Oratorium św. Jana Chrzciciela urządził referendarz koronny, ks. Jan Władysław Przerembski, kanonik tarnowski Dominik Gorecki obdarował kaplicę Mariacką, a tamtejszy infułat, Piotr Stanisław Orłowski, został głównym benefaktorem kaplicy św. Piotra ${ }^{21}$. Ostatni z dobrodziejów zasługuje też na uwagę jako autor innych ambitnych fundacji. Prawnik, kolega Piskorskiego ze studiów, sprowadził do kolegiaty w Tarnowie bogatą kolekcję relikwii, łącznie z całym ciałem św. Felicyssyma, a także sprawił liczne relikwiarze i paramenty ${ }^{22}$. Trzy lata przed jego śmiercią tamtejsza kapituła zdecydowała o budowie osobnej kaplicy relikwii, którą w roku 1712 wzniesiono nad zakrystią na kształt i sposób kaplicy św. Jacka w Krakowie, ale urządzono dopiero w latach 30. wieku XVIII²3.

Piskorski, Orłowski i Przerembski urządzili kaplice swoich patronów, a przekaz o motywacji dwóch dalszych benefaktorów można znaleźć w książce Buchowskiego. Najwięcej napisał on o Myszkowskim, sławiąc jego znawstwo i zamiłowanie do wspaniałych dzieł architektury oraz kult czystości, które skłoniły go do wsparcia kaplicy św. Józefa ${ }^{24}$. Matematyk wspomniał też, że Suszycki, profesor praw, słynny jako wszechstronny uczony wychowawca królewiczów Aleksandra i Konstantyna, ozdobił kaplicę św. Katarzyny, patronki filozofów, był więc zapewne jej czcicielem jako członek wspólnoty akademickiej ${ }^{25}$. Kaplica Mariacka została natomiast opisana jako urządzona $z$ ofiar pewnych donatorów ${ }^{26}$. Górecki został więc pominięty albo z powodu własnej skromności, albo też dlatego, że pokrył tylko 2000 z $3694^{27}$.

\footnotetext{
21 AUJ, 318, s. 43-47, 249-263.

22 KurZej 2018a, s. 272.

23 HerzIG 1900, s. 98, 100, 151. W roku 1780 kaplicę przekształcono, zrównując jej poziom z nawą, a w roku 1826 ostatecznie zlikwidowano.

24 Consummate enim Herois illius rerum cognitio, elegantiorum archiecturae operum amor, munditiei cultus et erecta ad politioris vitae dignitatem prudentia, solo decoris Domini adore ad exornandum D. Iosephi Sacellum trahebatur. Cyt. za: BUCHOWSKi 1703, k. g3v.

25 Sacelum [...] adornatum [...] a munifica manu [...] Remigii Suszycki, UI doctoris, archidiaconi Crac., scholastici Lencicen. et c. viri literarum plenitudine celberrimi, et in iis, quondam Serenissimorum Polonie Principium Alexandri et Constantini gubernatoris. Cyt. za: BUCHOWSKI 1703, k. g2v.

26 Pientissima benefactorum nonullorum munificentia. Cyt. za: BUCHOWSKI 1703, k. g4r.

27 AUJ, 318, s. 44, 254.
} 


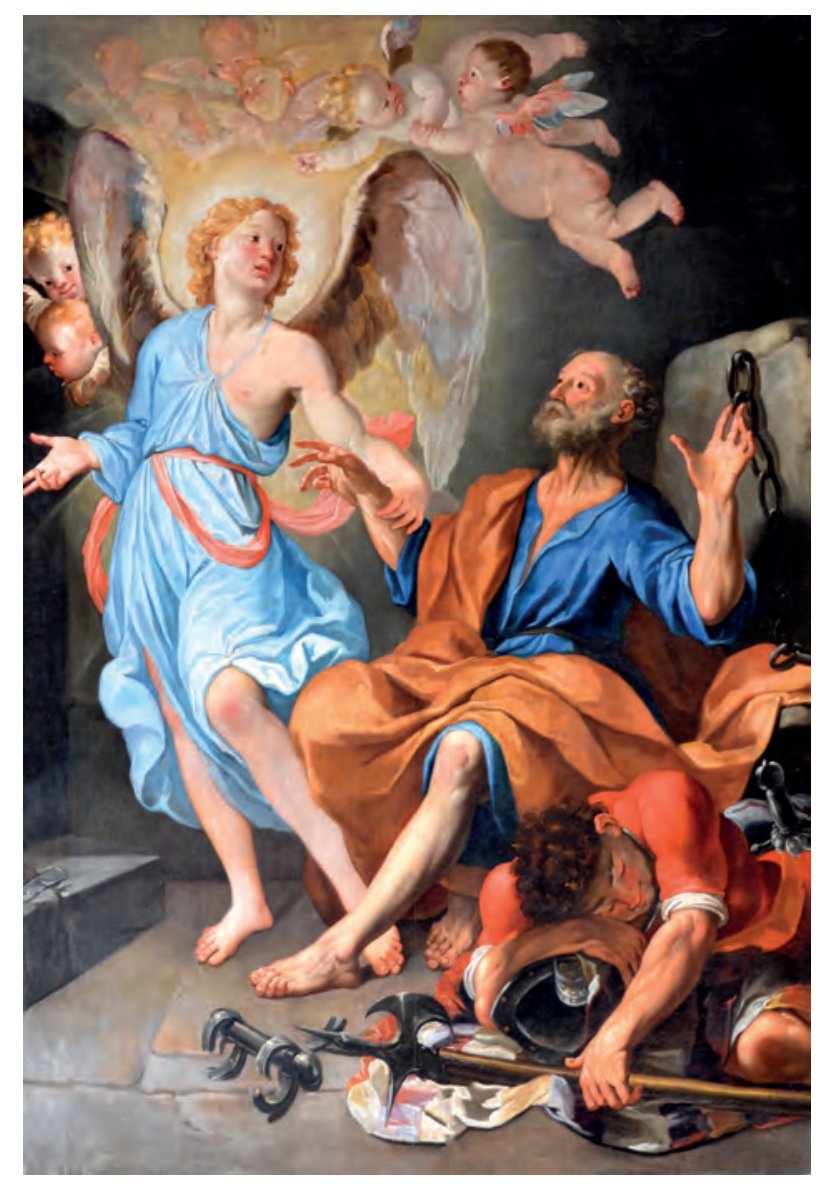

9. Kraków, kościół św. Anny, Innocenty Monti, Święty Piotr, fot. autor, 2017

Co bardzo charakterystyczne, wkład dobrodziejów poszczególnych kaplic upamiętniono wyłącznie w sposób literacki. Ich nazwiska znalazły się nie tylko we wspomnianej pracy Buchowskiego; zostały też wyliczone obok innych benefaktorów w aneksie do kazania, które Piskorski wygłosił z okazji konsekracji kościoła ${ }^{28}$, a wysokość ich wpłat odnotowano w księdze rachunkowej przekazanej przez niego do biblioteki uniwersyteckiej ${ }^{29}$. W kaplicach nie przewidziano inskrypcji czy znaków odnoszących się do ich dobrodziejów. Wyjątkiem jest godło Orłowskiego wrysowane w ramę obrazu kaplicy św. Piotra. W kaplicach nie ma też miejsc na epitafia, a przynajmniej dla części z nich nie przewidziano chyba w ogóle funkcji grobowej. Podziemia kościoła nie były - o ile mi wiadomo - od dawna otwierane, ale w XIX

\footnotetext{
28 PisKorski 1706, s. 1049-1054; pominięto tam Góreckiego, a Przerębskiego wymieniono bez adnotacji o kaplicy.

29 AUJ, 36, s. 316, 317.
} 
wieku znano trzy krypty: „publiczną” pod przęsłem krzyżowym, „kolegiacką” pod zakrystią i „akademicką" - pod kaplicami po stronie Epistoły ${ }^{30}$. Przyjmując, że jest to stan pierwotny, trzeba by założyć, że nie miały być miejscem spoczynku fundatorów. Wskazuje na to pochówek Piskorskiego, który nie spoczął pod oratorium swojego patrona, ale w krypcie pod przeciwległą kaplicą św. Józefa, o której w testamencie napisał, że mu jakby przypadkiem przypadła ${ }^{31}$.


10. Kraków, kościół św. Anny, Innocenty Monti, fot. autor, 2017

Biorąc pod uwagę rangę kościoła jako akademickiej kolegiaty, najbardziej reprezentacyjnego budynku uczelni i jej artystycznego symbolu, może dziwić fakt, że tak niewiele miejsca przeznaczono w nim na upamiętnienie poszczególnych członków wspólnoty akademickiej. W czasie budowy powstały tylko dwa skromne napisy na portalach prowadzących z prezbiterium do zakrystii i kapitularza. Pierwszy z nich upamiętnia Pawła Wojewódzkiego, z którego testamentu przeznaczono 600 złotych polskich na wykonanie jednego z obramień, drugi zaś - Krzysztofa Sowińskiego, który przekazał nieporównywalnie większą sumę 8833 złotych polskich na wykonanie ołtarza głównego ${ }^{32}$. Piskorski przewidział też zapewne wmurowanie kolejnych epitafiów w niewielkich przęsłach po bokach chórowego, pełniących funkcję przedsionków do obu ciągów kaplic. Na ich sklepieniach namalowano bowiem dusze wielbiące piękno przybytku i pragnące przebywać w jego przedsionkach, zidentyfikowane wersetami Psalmu 84: Quam dilecta tabernacula Tua i Concupiscit anima mea in atria domini (il. 10). Co ciekawe, komemoratywna

30 Tylkowski 1863, s. 37, 38.

31 AUJ, 36, s. 313.

32 AUJ, 318, s. 37, 38, 47, 225-233, 264, 265. 
funkcja tych wnętrz doskonale wpisuje się w starą tradycję lokalizowania prestiżowych nagrobków przy fasadzie kościoła, której przykładem są chociażby kaplice przy fasadzie katedry krakowskiej ${ }^{33}$.

W tych niewielkich wnętrzach znalazło się miejsce tylko dla dwóch par pomników poświęconych osobom szczególnie zasłużonym dla kościoła. Pierwsza, z lat 20. wieku XVIII, upamiętnia samego Piskorskiego (zm. 1707) ${ }^{34}$ oraz Andrzeja Krupeckiego (zm. 1725), który pokrył dach kościoła blachą i ufundował liczne paramenty ${ }^{35}$. Drugą parę, wykonaną w latach 80., dedykowano Józefowi Rygalskiemu (zm. 1779), fundatorowi hełmów wię̇ ${ }^{36}$, oraz Antoniemu Żołędziowskiemu (1783), któremu udało się w końcu doprowadzić do kanonizacji św. Jana Kantego ${ }^{37}$.

Kościół św. Anny jest więc nie tylko przykładem rzadkiej sytuacji, w której odrębne finansowanie poszczególnych kaplic udało się pogodzić ze ścisłym zintegrowaniem ich wystroju z całością wnętrza, ale też bardzo specyficznej komemoracji ich dobrodziejów. Dotacja nie dawała im bowiem prawa do wystawienia okazałego nagrobka, a prawdopodobnie też nie gwarantowała przywileju pochówku w kościele. Ich upamiętnienie $\mathrm{w}$ książce wydanej z okazji konsekracji można więc odczytać jako specyficzny wyraz kultury akademickiej, skoncentrowanej na słowie pisanym, a także odwołującej się często do księgi jako uniwersalnego symbolu mądrości. W kościele św. Anny jest to wszak główny motyw wnętrza, powtarzający się jako atrybut patronki, spis ziemskich przodków jej wnuka, dowód świętości Jana Kantego, znak wiedzy antycznych prorokiń oraz godności Baranka Apokaliptycznego jako Najwyższej Mądrości Bożej ${ }^{38}$. W tym kontekście drukowana monografia budowli, zawierająca streszczenie programu oraz ważniejsze wiadomości historyczne, mogła się więc wydawać pamiątką najbardziej godną i właściwą dla uczonych ofiarodawców.

\footnotetext{
33 Na temat tej tradycji zob. WALCZAK 2014, s. 157.

34 Większość kosztów epitafium pokrył niegdysiejszy wychowanek profesora, prymas Stanisław Szembek (AUJ, 319, s. 26). Autorem struktury był kamieniarz Wojciech Maciejowski.

35 Według napisu na epitafium: Collegii Iuridici insignis benefactor sed maxime huius basilicae quam cupro ingenti sumptu bene totam texit, argentea supellectili pretiose ornavit, ipse moribus commitate et vita ornatissmus. Na jego temat zob. BACZKOWSKA 1970; FOKT 2015.

36 Według napisu na epitafium: turres istius templi aere pannonio tectas astris intulit. Zasługę tę odnotowano też na na modelu hełmów zachowanym w Muzeum UJ: M[agister] Joan[nes] Josephus Rygalski S[acrae] T[heologiae] D[octor] Eccle[siae] Coll[egiatae] S[ancti] Floriani Custos Geminam hanc turrim ad aedem Divae Annae Anno Jubilaei Magni 1775 erexit, a także w księdze rachunkowej, na epitafium Rygalskiego w Starym Korczynie oraz w dziękczynnym czterowierszu (PUTANOWICZ 1780, k. T2r). Na temat Rygalskiego zob. BACZKOWSKA 1992.

37 Zasługę Żołędziowskiego dla kanonizacji Kantego wspomniano w jednym z wierszy Stanisława Kruszyńskiego, które wygłoszono podczas krakowskich uroczystości kanonizacyjnych: Ze wszech miar Żołędziowski godzien bydź wielbiony!/ Jemu Akademia winne zanosi ukłony!/ Jego lat kilkunastu, praca y zabiegi/ Sprawiły; iż Jan w Świętych policzon szeregi./ Trzem wieki tylu mężów pociły się głowy, / Ciagnąc Kantego w Rzymie cnót, cudów osnowy./ On ieden uskutecznił tak zbawienne myśli,/ Przetoż Mu sprawiedliwość tako kolos kryśli (PUTANOWICZ 1780, k. Ii2r). Na temat Żołędziowskiego zob. HajDUKIEWICZ 1966, s. 387.

38 KurZej 2018a, s. 117, 118, 126, 141.
} 


\section{Bibliografia}

AUJ, 37 - Archiwum Uniwersytetu Jagiellońskiego, rękopis 36, Liber Testamentorum et ordinationum post defunctos admodum reverendos \& clarissimos D[ominos] Professores Academiae Cracoviensis, 1645-1758.

AUJ, 318 - Archiwum Uniwersytetu Jagiellońskiego, rękopis 318, Rationes Perceptorum et Expensorum Pro Fabrica Ecclesiae S. Annae Crac[oviensis].

AUJ, 319 - Archiwum Uniwersytetu Jagiellońskiego w Krakowie, rękopis 319, Liber Perceptorum \& expensorum pro Ecclesia Collegiata S. Annae Crac[oviensis] cum connotatione Benefactorum.

BACZKowsKa 1970 - Wanda Baczkowska, Krupecki Andrzej Grzegorz, [w:] Polski słownik biograficzny, t. 15, Wrocław-Warszawa-Kraków 1970, s. 405-406.

BACZKOwsKA 1992 - Wanda Baczkowska, Rygalski (Rygalik) Jan Nepomucen Józef, [w:] Polski słownik biograficzny, t. 33, Wrocław-Warszawa-Kraków 1992, s. 459-461.

BAXNADAlL 1974 - Michael Baxandall, Painting and Experience in Fifteenth Century Italy, LondonNew York 1974.

Buchowski 1703 - Andrzej Buchowski, Gloria Domini super Templum [...] S. Annae [...], Cracoviae 1703.

BuKOwsKi 1900 - Julian Bukowski, Kościół akademicki św. Anny. Monografia historyczna, Kraków 1900.

DANIELI 2009 - Francesco Danieli, San Filippo Neri. La nascita dell'Oratorio e lo sviluppo dell'arte cristiana al tempo della Riforma, Cinisello Balsamo 2009.

FOKT 2015 - Krzysztof Fokt, Krupecki Andrzej Grzegorz, [w:] Profesorowie Wydziału Prawa Uniwersytetu Jagiellońskiego, t. 1: 1364-1780, Kraków 2015, s. 210-212.

HAJDUKIEWICZ 1966 - Leszek Hajdukiewicz, Biblioteka Jagiellońska w latach 1655-1775, [w:] Historia Biblioteki Jagiellońskiej, t. 1: 1364-1775, red. Ignacy Zarębski, Kraków 1966, s. 275-426.

HASKELl 1963 - Francis Haskell, Patrons and painters. A study in the Relations Between Italian Art and Society in the Age of the Baroque, London 1963.

HerZIG 1900 - Franciszek Herzig, Katedra niegdyś kollegiata w Tarnowie, Tarnów 1900.

Hirschfeld 1968 - Peter Hirschfeld, Mäzene. Die Rolle des Auftraggebers in der Kunst, BerlinMünchen 1968.

IGNASZEWSKA 1976 - Franciszka Salezja Ignaszewska, Fundacja Małachowskiego, „Rocznik Krakowski”, t. 24 (1976), s. 89-106.

KARPOWICZ 1990 - Mariusz Karpowicz, Baldasar Fontana 1661-1733. Un Berniniano ticinese in Moravia e Polonia, Lugano 1990.

KLEIN 1909 - Franciszek Klein, Akademicki kościót św. Anny w Krakowie. Studium architektury, „Rocznik Krakowski”, t. 11 (1909), s. 53-63.

KRACIK 2003 - Jan Kracik, Wspaniałe Bogu wystawione dzieło. Jak w Krakowie kościót świętej Anny budowano, Kraków 2003.

KuRZEJ 2008 - Michał Kurzej, Budowa i dekoracja kościoła św. Anny w świetle źródeł archiwalnych, [w:] Fides ars scientia. Prace $z$ historii i historii sztuki poświęcone pamięci ks. Augustyna Mednisa, red. Andrzej Betlej, Józef Skrabski et al., Tarnów 2008, s. 271-301 [wznowienie w: Studia $z$ dziejów kościoła św. Anny, red. Zdzisław Kliś, Tomasz Węcławowicz, Kraków 2009, s. 139-200, wyd. 2, Kraków 2011, s. 137-199].

KURZEj 2012 - Michał Kurzej, Siedemnastowieczne sztukaterie w Małopolsce, Kraków 2012.

KuRZEj 2018a - Michał Kurzej, Depingere fas est. Sebastian Piskorski jako konceptor i prowizor, Kraków 2018. 
KuRzej 2018b - Michał Kurzej, Oltarz jako okno i lustro w koncepcjach ks. prof. Sebastiana Piskorskiego, „TECHNE. Półrocznik Katedry Historii Sztuki Uniwersytetu Łódzkiego” 2008, nr 1, s. 223-240.

Lepiarczyk/Przybyszewski 1991 - Józef Lepiarczyk, Bolesław Przybyszewski, Katedra na Wawelu $w$ wieku XVIII. Zmiany jej wygladu architektonicznego i urzadzenia wnętrz na podstawie badań historyczno-archiwalnych, [w:] Sztuka baroku. Materialy sesji naukowej ku czci śp. profesorów Adama Bochnaka i Józefa Lepiarczyka..., Kraków 1991, s. 21-38.

Levy 1999-2000 - Evonne Levy, The Institutional Memory of the Roman Gesù. Plans for Renovation of the 1670s by Carlo Fontana, Pietro da Cortona and Luca Berrettini, „Römisches Jahrbuch der Bibliotheca Hertziana", t. 33 (1999-2000), s. 373-426.

MAŚLIŃSKA-NowAKOWA 1969 - Zofia Maślińska-Nowakowa, Formy słowno-obrazowe dekoracji kościoła św. Anny w Krakowie, [w:] Treści dzieła sztuki. Materiały sesji SHS 1966, Warszawa 1969, s. 195-213.

MAŚLINSKA-NOWAKOWA 1971 - Zofia Maślińska-Nowakowa, Literackie źródła dekoracji kościoła św. Anny w Krakowie, „Rocznik Krakowski”, t. 42 (1971), s. 33-62.

MossaKowski 1965 - Stanisław Mossakowski, Charakterystyka i geneza formy architektonicznej kościoła św. Anny w Krakowie, „Rocznik Krakowski”, t. 37 (1965), s. 39-62.

NATOŃSKI 2002 - Bronisław Natoński, Jezuici a Uniwersytet Krakowski w XVI wieku, Kraków 2002.

Pagaczewski 1909 - Julian Pagaczewski, Baltazar Fontana w Krakowie, „Rocznik Krakowski”, t. 11 (1909), s. 2-50.

PIsKORSKI 1706 - Sebastian Piskorski, Kazania na dni Pańskie, na uroczystości Bogarodzice Panny Niepokalanie Poczętey, na święta osobliwe Stug Pańskich, w różnych kościołach odprawione, a dla duchownego pożytku pobożnemu czytelnikowi zostawione, Kraków 1706.

Putanowicz 1780 - Józef Alojzy Putanowicz, Życie, cuda i dzieje kanonizacji S. Jana Kantego [...], Kraków 1780.

ŚNIEŻyŃSKa-STOLOT 1981 - Ewa Śnieżyńska-Stolot, Pojęcie mecenatu artystycznego, „Folia Historiae Artium", t. 17 (1981), s. 5-13.

TYLKOWSKI 1863 - Marcin Tylkowski, Krótki opis kościoła akademickiego kollegiaty Świętej Anny w Krakowie, Kraków 1863.

URBAN 1964 - Wacław Urban, Akademia Krakowska $w$ dobie reformacji i wczesnej kontrreformacji (1549-1632), [w:] Dzieje Uniwersytetu Jagiellońskiego w latach 1364-1764, t. 1, red. Kazimierz Lepszy, Kraków 1964, s. 253-307.

WALCZAK 2014 - Marek Walczak, Topografia nekropolii królewskiej na Wawelu w średniowieczu, [w:] Procesy przemian w sztuce średniowiecznej. Materialy z konferencji Stowarzyszenia Historyków Sztuki we Wrocławiu w dniach 21-22 listopada 2013, red. Rafał Eysymont, Romuald Kaczmarek, Warszawa 2014, s. 147-161. 


\section{Chapels of the collegiate church of St. Anne in Cracow - individual foundations under collective supervision}

$\mathrm{T}$ he artistic history of the university collegiate church in Cracow, has been the subject of numerous studies. Focusing on its chapels, however, imposes a slightly different perspective, related to the issues of patronage over individual oratories and the way in which their decoration was included in the ideological and artistic program of the entire church. After adopting such perspective, the Church of St. Anna appears as an interesting contribution to the reflection on the phenomenon of collective patronage, perfectly confirming the view of Peter Hirschfeld and Michael Baxandall, according to which the term basically refers to the activities of an individual hidden behind the collective. One of the goals set by the creators of the magnificent modern church with a rich liturgical and architectural program was to achieve the greatest possible coherence of the decor, both in terms of ideology and art. The obstaclesin its achievement were often complicated ownership relations, resulting from the diversified patronage over the chapels. Cracow Church of St. Anne, erected in the years 16931703 under the supervision of prof. Sebastian Piskorski, is one of the rare examples where the chapels have been given a coherent content and artistic program, despite the fact that their interiors were decorated thanks to money providedby separate founders. To achieve this harmony, the inclusion of the chapels in the content program of the interior was of the utmost importance, especially due to the transept chapels. It was in one of them that the altar of the tomb of St. John Cantius had to be placed, and such a location allowed direct light to be shone on it on the anniversary of saints' birthday. Special setting had to be provided also for the opposite chapel of St. Cross, which reminded of the saints' passionate devotion and presented the Cross as a source of wisdom. Much attention was paid to smaller nave oratorios. There are three pairs of them, the middle of which has been distinguished by a higher dome with a lantern. The choice of patrons of the nave chapels is allegorical - the middle chapel on the Epistle side was dedicated to the Virgin Mary, and the neighboring ones - to her spouse, St. Joseph and relative, St. John the Baptist. Moreover, the John Baptist's Oratory is adjacent to the mausoleum of John Cantius, who was born on the Midsummer Day, inheriting his name. On the other hand, the chapels on the Gospel side were dedicated to figures representing the Church of times of the New Covenant. Its first superior - St. Peter, following Christ in martyrdom, was commemorated next to the Chapel of St. Cross. The middle oratory, opposite the St.Mary's Chapel, is dedicated to St. Catherine the virgin, and the last - St. Sebastian, the patron of Piskorski, but also a popular apostle of those suffering infectious diseases. What is very characteristic, the contribution of the benefactors of individual chapels was commemorated only in a literary way - in publications issued on the occasion of the completion of the construction of the church. There are no inscriptions relating to their benefactors or space for their epitaphs in the chapels, or at least some of them have no funeral function at all.

Keywords: early modern art, church, chapel, Sebastian Piskorski, Jagiellonian university 